\title{
Women \& Patriarchy in Vrat Kathas: A Study
}

Religious rituals typically involve disciplining or controlling some element of the body or bodily desires, but for women that may entail being subjected to ritual practices aimed at controlling them and reinforcing male domination. (Talukdar, 2014)

The celebration of (Hindu) festivals ${ }^{\mathrm{i}}$ is tied up with the ideas of patriarchy enacted via religious institutional frameworks that demand penance in fore-thought as part of absolution for one's self for this life and the next and the next. In other words, these are mechanisms in place that actively work to hypnotize the female while working to disempower them thoroughly and repeatedly. It works as a corrective measure for upholding the socio-religious behaviors of its members (women, really) via kinship rules of moral policing and virtue reinforce-r. These cultural tokens personify patriarchal teachings, ensuring the borders and structures of ideal/acceptable female behavior by means of "reward-punishment" dichotomy, motivating cooperation and submission.

The 'festival' is ostentatiously observed by women (folk). This is not simply a matter of tradition or practice, but is in fact coded into the "katha $\mathrm{i}^{\mathrm{ii}}$ ' that is to be heard with veneration, for apparently reading kathas throughout the consortium of various fasts and festivals is not only not encouraged, but never even mentioned, despite modern inductions of such phrases/facts as "police-feariii", etc. The religious tales for the purposes of affording a structural framework of the ritual fasts are called vrat kathas ${ }^{\mathrm{iv}}$, a part of the larger categories of religious fables: didactic or otherwise. 
This is what popular means of devotion and/or piety looks like for the mass Hindus who practice the religion with more or less similar rituals, meanings and values: numerous fasts notwithstanding the weekdays' one (for literally every day of the week) held mostly or almost exclusively by women, least for themselves. While the sociological repercussions for the roundabout way of practicing patriarchy is lengthy and requires much inquiry and time to examine and explain, it is nevertheless not a concern for the present paper.

Some facts of the popular and venerated fast of Teej, known variously as Haryali Teej, Hartalika Teej, Kajari Teej and various other regional varieties mostly in Central and Northern India as well as Nepal. As it is a sort of veneration of the fertility and new life of the monsoon season, it is celebrated in the month of Shravan (sawan) and Bhadrapad, the third day after the full moon or the new moon respectively, in the Hindu calendar. (Wikipedia)

The case is examined via a close reading of the 'katha' of Teej that is, by various accounts, at least close to the varieties followed in the Gangetic doab stretching the states of UP and Bihar predominantly (where Kajari Teej is celebrated and kajris ${ }^{\vee}$ are customarily sung). The katha chosen is printed in (simple, everyday) Hindi, of which personal translations have been made for study for the sake of this paper.

A cursory plot of the katha is that the god Shiva narrates the story of (one of the most difficult and ardent) fasts of Parvati ${ }^{\mathrm{vi}}$ to Parvati herself on her earnest request.

Though the 'katha' mentions the divinity of both deities, the female is clothed in "divine clothes" while the superior male is masquerading naked (however, he is shown in pictures as wearing clothing like sages, or the Graeco-Roman toga; though his worship in lingam form is symbolic of imminent virility and fertility, eternally). 
While narrating Shiva mentions the acute difficulty of the fast in question, while Parvati reiterates the difficulty but worth of such a 'tap' which is solely responsible (along with the associated vrat and daan) for her getting Shiva (as husband).

And this is how she has managed to get "equal status" via the relationship to the great first. [Shiva's words]

\# Despite the fact that Parvati has done this vrat (as Shiva acknowledges forthright)- meaning she is capable of doing something of her own accord (resourcefulness, determination and wisdom), it is the non-participant Shiva narrating the story (katha) for the benefit of all potential observers of the fast.

[Parvati's vrat/tap lasted for 12 years, in self-exile, which for the mortal women is reduced to about 24 hours or so of hard fast, which is all ultimately for the benefit of entire womankind]

As a (mere) token of equality that the concerned deities exhibit, the katha does call for "woman and man" to pray together, but fails to mention their relationship [the kathas of this kind are notorious for writing husband and wife in clear instances] or enforced value of their act or even its prevalence or mandate.

Women protect their good future and happiness for seven lifetimes if they undertake this 'simple' fast. Though it starts as encouraging and seemingly optional (or by choice at the very least), it ends as a rather threatening note- suddenly outlining the condemnation to be faced by non-fasting women (no exceptions are mentioned in this version) who are glutton for food.

This condemnation includes going to hell (seemingly antithetical to Hindu philosophy that lacks Judgment Day as well as 
eternal solution), remaining a slave for seven lives, repeatedly becoming a widow, being poor (endless poverty), facing constant misery specific to son (an insolent son, etc.), being endlessly unhappy, and similar curses.

$>\quad$ The normal eating is transformed to monstrous gluttony (with harsh, non-sensical judgments: basically a variety of animals) on the day of fast for women who foolishly dare to eat-

$\checkmark \quad$ Eating meat makes them tigress; curd makes them cat; sweets make them ants; and, 'anything' makes them a housefly.

Additionally, fruits make them monkey; drinking milk makes them snake; water makes them parasitic \& sleeping makes them a python.

$\checkmark \quad$ Also, unclear thoughts are a betrayal towards the husband and make the thinker a hen. (However, it is perhaps quite unrelated to the English word 'cuckold'.)

THIS vrat is to be done so that the women may get 'husbands' like Shiva and dying (near-death) makes them Parvati-like. What all of this means, including the symbolism of the cursed animals, however, is quite unclear and never spoken about, meaning perhaps, that apparently all threats and rewards are to be taken at face value. In the above paragraphs, the katha of Teej has been analysed via close reading of the Hindi versions of it, popular in the market-stall variety katha books as opposed to some archaic/ arcane Sanskrit (or priestly) 
versions to understand what material the masses generally have access to and look to for codes of conduct.

Pearson (Pearson, 1996) deals with the question of whether Hindu women are subordinated and disempowered by their following largely Brahmanic texts during their vrat observances, and concludes that while it has its own nuances and regional as well as caste differences, it favours the systemic oppression of women at large, by women themselves by inculcating feelings of piety and self-virtue (and feelings of superiority over the irreligious ones). She also says that creating a sense of achievement and spiritual satiety is what keeps the women stuck in the cycle of following vrats and its rituals and introducing it to the next generation and fellow followers. Combined with self-discipline, it manages to make it seem empowering for most women who choose to defend it with their own internal logic (which was found via a common asking around of women in my own community).

If Bynum's (Callegari, 2018) insistence on food as "presence and power" in its relationship to women could be applied here, it would be obvious, that though noticeably different, her claims about medieval Italian mystical women is quite similar to the nature and experience of fast-observing Hindu women who treat the abstinence of food as righteous. Bynum explains that food becomes a means of communication and self-definition for those abstaining women, which also applies, in a devout sense, to Hindu women's vrat observance. Also applicable is her conclusion, that women (as opposed to non-women ${ }^{\mathrm{vii}}$ ) are disproportionately the ones to practice these forms of mystical disciplines, because they share a closer (almost exclusive) relationship with food and its habits, as they are the primary carers of food-based actions. However, while Bynum's claims are based on women who have complete personal 
choice and little religious precedent, Hindu women are following rigid Brahamanico-patriarchal pronouncements with close community and familial monitoring. ${ }^{\text {vii }}$

Paul Tillich's notion of "ultimate concern"ix and Mircea Eliade's notion of the "sacred"x (regarding what religion is and means) combine to define what vrat signifies for its observers who are inclined to cling closer to something so personally beneficial and of divine precedence. While many explanations reside for why vrats are observed or exist, the vrat kathas themselves hold an unassailable place at the apex of female reverence, vouched for by experienced practitioners and enforced continually by religious institutions.

While contemporary scholarships (Talukdar, 2014) have indicated satisfactorily that women are capable of co-opting religious symbols and mechanisms to make their own point or practice chosen individuality and even socio-political activism, it is quite far from being applicable to the vrat practice of Hindu women, even though some vrats and related kathas (for example, karva-chauth) have gathered glamour and fabled status of "love" and "devotion" to being subservient to male counterparts. 


\section{Works Cited}

Bynum, C., 1985. Fast, Feast, and Flesh: The Religious Significance of Food to Medieval Women. Representations, 11, pp.1-25.

Bynum, C., 1988. Gender And Religion. Boston: Beacon Press.

Callegari, D., 2018. Fast, Feast and Feminism: Teaching Food and Gender in Italian Religious Women's Writings. Religions, 9(2), p.56.

Eliade, M., 1959. The Sacred And The Profane. 1st ed. New York: Harcourt, Brace \& World.

Pearson, A., 1996. "Because It Gives Me Peace Of Mind": Ritual Fasts In The Religious Lives Of Hindu Women (Mcgill Studies In The History Of Religions). Albany: State University of New York Press.

Plato.stanford.edu. 2020. Concepts Of God (Stanford Encyclopedia Of Philosophy). [online] Available at: <https://plato.stanford.edu/entries/concepts-god/> [Accessed 20 October 2020].

Talukdar, J., 2014. Rituals and Embodiment: Class Differences in Religious Fasting Practices of Bengali Hindu Women. Sociological Focus, 47(3), pp.141-162. 


\section{Author Bio}

Rani Singh is finishing her postgraduate in one of the few universities of India which offer Gender Studies, at Jamia Millia Islamia University in New Delhi. Her research interests are in the fields of gender studies and sociology; particularly, socio-economic inter-sectionality of women's status (class and caste) in rural and semi-urban India, and alternative genders with a special focus on the Indian transgender community. 


\section{Notes}

${ }^{\mathrm{i}}$ However, most festivals, regardless of origin-religion, are patriarchal institutions as well as tools. Burke uses the term: "gender-traditional" religion for expressing the same.

ii Any kind of story or narration. Here, religious didactics as part of observing fasts and/or festivals.

iii This in particular is an example from the katha for Friday fasts in honour of the goddess of wealth and fortune, Lakshmi.

iv Lit. Fast stories/narratives.

${ }^{\mathrm{v}}$ Kajris are a kind of folk songs prevalent in (large parts) of the states of Bihar and UP, as well as, Rajasthan and Madhya Pradesh.

${ }^{\text {vi }}$ For the purposes of the festival, also known as Teej mata (lit. Teej mother).

vii The phrase is meant to overcome rigid and polar-opposites gender constructs.

viii This 'monitoring', in part, is exercised by constant humiliation as being "unwomanly" or "devil-woman", and so on.

ix This is the essence of religious attitudes and is "total" in terms of complete surrender with promises of 'total' fulfillment.

$x$ 'Sacred', as the "the intentional object of human experience that is apprehended as the real", and on the contradictory axis of the 'profane', via understandably coherent religious symbols. 